\title{
Factors Hindering The Effect of The Nebulization Therapy among Critically Ill Mechanically Ventilated Patients
}

\author{
Abd Elrhman Sami Shabaan Eltabakh, Clinical Instructor \\ Critical Care and Emergency Nursing, Faculty of Nursing, Matrouh University.
}

\author{
Suad Elsayed Abdelmotalb Elsman, Assistant Professor \\ Critical Care and Emergency Nursing, Faculty of Nursing, Alexandria University.
}

\author{
Sahar Hossni Elsayed El-Shenawi, Lecturer \\ Critical Care and Emergency Nursing, Faculty of Nursing, Alexandria University.
}

\author{
Ahmed Mohammed Nabil Ahmed Abdullah, Lecturer \\ Critical CareMedicine, Faculty of Medicine, Alexandria University.
}

\begin{abstract}
Background: Nebulization therapy is used for many therapies now including bronchodilators and corticosteroids and has a significant advantages superior to other routes of administration. However, it has many draw backs. Objective: To identify factors hindering the effect of nebulization therapy among critically ill mechanically ventilated patients. Settings: four intensive care units at Alexandria Main University. Subjects: A convenience sample of 60 adult critically patients on invasive MV and, all critical care nurses about 50 nurses who were involved in providing direct patient care and working in the three different shifts. Tool: "Factors hindering the effect of nebulization therapy among mechanically ventilated patients' assessment" was used to collect the needed data. Results: Findings of the current study revealed that there was a significant improvement in almost cardiovascular and respiratory parameters $\left(\mathrm{p}=<0.001^{*}\right.$ for all) after the nebulization therapy session with 4 hours, while Majority of the nurses had unsatisfactory level of performance regarding to nebulization therapy especially in the night shift with significant value for total score ( $\mathrm{p}=0.006^{*}$ for all). Conclusion: slower inspiratory flow, longer duty cycle, and large diameter tracheal tubes gives betters and effective nebulization. Recommendations: Frequent check of the ventilator parameters and connections before nebulization therapy, also providing frequent in- service training programs for the nurses related to the correct technique for nebulization therapy administration.
\end{abstract}

Keywords: Factors, hindering, nebulization, therapy, effect, critically ill, mechanically ventilated patients.

\section{Introduction}

MV is frequently used to provide respiratory support in times of critical illness. The main goals of MV are oxygenation and carbon dioxide elimination, which are ensured by maintaining adequate tidal volumes and respiratory rates (Warner andPatel, 2012). Nurses are administering the nebulizer on MV regularly at the ICU to administer medications to the mechanically ventilated patients (Ellis et al., 2013).

It is believed that the beneficial effects of inhaled drugs are smaller in patients on MV than in those breathing spontaneously. In an early study, only $2.9 \%$ of the administered dose reached the distal airway versus $11.9 \%$ when the dose was administered without an artificial airway (Maccari et al., 2015).

Despite several novel therapies and devices that reported in the literature regarding nebulization therapy, A few studies handle the factors that may hinder the nebulization therapy effectiveness and the proper technique for performing nebulization therapy for the critically ill patients on MV.

\section{Aims of the Study}

This study aims to identify factors hindering the effect of nebulization therapy 
among critically ill mechanically ventilated patients

\section{Research Questions}

What are the factors hindering the effect of nebulization therapy among critically ill mechanically ventilated patients?

\section{Materials and Method}

\section{Materials}

\section{Research design:}

A descriptive research design was used to conduct this study.

\section{Settings:}

This study was carried out at Alexandria Main University Hospital in four intensive care units namely: Causality Care Unit; and General Intensive Care Units (unit II), (unit III), and (unit IV).

\section{Subjects:}

- A convenience sample of 60 adult critically ill hemodynamically stable patients on invasive MV and receiving nebulization therapy through mechanical ventilator for at least three days in the previously mentioned units were recruited for this study. Using the equal allocation method, a convenient sample of 50 nurses was selected from each of the previously mentioned settings.

- The patients were selected based on the power analysis using the Epi-info. Program to estimate the sample size using the following parameters: Population size $=300$ in three months, Expected frequency $=50 \%$, Expectable error $=5 \%$, Confidence coefficient $=95 \%$, Minimum sample size $=180$ patients.

- All critical care nurses from different nursing categories 50 nurses who were involved in providing direct patient care and working in the three different shifts (morning, evening, and night) in the previously mentioned units and welling to participate in this study.

\section{Exclusion criteria:}

All patients who ha the following criteria were excluded from the study: Patient who needed nebulization therapy for less than three days, weaned from mechanical ventilator before three days, discharged to the hospital ward or transferred to another hospital, or died before three days.

Tools: In order to collect the necessary data for the study, one tool was used:

Factors hindering the effect of nebulization therapy among mechanically ventilated patients' assessment". The tool was developed by the researcher based on reviewing the related literatures (Ari andFink, 2010; and Fink andAri, 2017). This tool included two main Categories: the first category related to assessment of the factors hindering the effect of the nebulization therapy among mechanically ventilated patients; and the second category related to assessment of the patients' response to the nebulization therapy.

\section{Method:}

- An approval from the ethical committee, Faculty of Nursing Alexandria University was obtained.

- An official permission was obtained from the Faculty of Nursing Alexandria University to the administrative authorities of the Alexandria Main University Hospital to conduct the study.

- An official approval was obtained from the hospital administrative authorities to collect the necessary data from the selected settings after explanation of the aim of the study.

- The tool "Factors hindering the effect of nebulization therapy among mechanically ventilated patients' assessment" was developed by the researcher after reviewing the related literatures.

- Content validity was done for the tool by a jury of seven experts in the field of the study, and suggestions of the jury members were 
- reviewed and the tool was modified as indicated.

- Pilot study was carried out on five critically ill patients and five critical care nurses to evaluate the clarity and applicability of the tool and necessary modifications were done accordingly.

- Reliability of the tool was done before conducting the study using Cronbach Alpha reliability, the reliability coefficient was $(\mathrm{r}=$ 0.880 ) which is reliable.

- Factors hindering the nebulization delivery during MV were assessed for each mechanically ventilated patient by using the six parts of the first category of the tool.

- Patients on invasive MV were enrolled in the study according to the previously mentioned inclusion criteria.

\section{Statistical analysis:}

After data were collected, they were coded and transferred into specially designed formats so as to be suitable for computer feeding. Following data entry, checking and verification processes were carried out to avoid any errors during data entry, frequency analysis, cross tabulation and manual revision were all used to detect any errors. The statistical package for social sciences (SPSS version 25) was utilized for both data presentation and statistical analysis of the results. The level of significance selected for this study was $\mathrm{P}$ equal to or less than 0.05 .

\section{Ethical considerations:}

- Witness informed written consent was obtained from head nurses for observation and intervention in this study after appropriate explanation of the study purpose.

- Written informed consent was obtained from patients' family for their participation and right to refuse of their patients' participation in the study was assured. Patients' privacy was respected.
- Anonymity and data confidentiality were assured during implementation of the study.

\section{Results}

Table I shows the distribution of the studied critically ill patients according to their characteristics. It was noticed that a third of the patients' age was in the group between 18 to 30 years old. It was noticed that all patients were admitted with respiratory disease, about half of the patients were admitted with renal, and cardiovascular diseases $(58.3 \%$, and $51.7 \%$, respectively). It was observed that about two thirds of the patients had GCS equal 3-8. A third of the patients had a length of stay equal 1-7 days.

Table II presents the distribution of the critically ill patients according to ventilator parameters. It was observed that all patients were recruited to pressure control ventilation. The measured inspiratory flow in a half of the patients (50\%) was more than $40 \mathrm{~L} / \mathrm{min}$. The calculated bias flow value in more than a half of the patients $(58.3 \%)$ was $2 \mathrm{~L} / \mathrm{min}$ or more. The calculated duty cycle value in majority of the patients $(80 \%)$ was more than 0.30 .

Table III presents the distribution of the studied critically ill patients according to nebulization therapy. It was noticed that all the nebulization sessions were done using jet nebulizer device, that was positioned between the airway and the circuit in less than two thirds of the patients $(60 \%)$. The received drugs were undiluted in more than a half of the patients $(53.3 \%)$, and the fill volume of the drug in more than a half of the patients $(55.7 \%)$ was $2 \mathrm{cc}$. The duration of each nebulization therapy session in more than two thirds of the patients $(71.7 \%)$ was 6-10 minutes. There was a residual volume of the nebulized drug in slightly less than a half of the patients $(45 \%)$, and the measured residual volume of the nebulized drug in near one quarter of the patients (23.3\%) was more than $2.5 \mathrm{ml}$.

Table IV represents the respiratory status of the patients before, immediately after, and 4 hours after nebulization therapy through the study days. It was noticed that a significant 
improvement in respiratory rate, tidal volume, and patient - ventilator synchronization 4 hours after session with significant difference $(\mathrm{p}=$ $<0.001^{*}$ for all). As regarding to air entry on the right lung, there was a significant improvement in the air entry on the right lung 4hours after the nebulization therapy session through the studied days, with a significant difference $\left(\mathrm{p}=0.031^{*}, 0.012^{*}\right.$, and $0.021^{*}$ respectively). It was noticed that the air entry on the left lung has significantly improved 4hours after the nebulization therapy session through the studied days, with a significant difference $\left(\mathrm{p}=0.042^{*}, 0.017^{*}\right.$, and $0.004^{*}$ respectively).

Table $\mathbf{V}$ describes the distribution of the studied critical care nurses according to their characteristics. It was noticed that near two third of the nurses were in the age group ( $<25$ years), slightly more than a half were males. About more than a half of the nurses had a baccalaureate degree, near a half of the nurses $(46.7 \%)$ had an experience in ICU5 years; and none of the nurses attend in service training regarding nebulization therapy.

Table VI demonstrates the comparison between the critical care nurses' level of performance of nebulization therapy during different working shifts. The table reveals that the majority of the nurses had unsatisfactory performance level related to nebulization therapy at night shift, with a significant total mean score and standard deviation of nebulization therapy steps in the different working shifts $\left(\mathrm{p}=0.006^{*}\right)$.

\section{Discussion}

The use of nebulized medications during $\mathrm{MV}$ is rising, and the delivery of drugs in aerosolized form to the airways of patients with pulmonary illnesses is a routine therapeutic practice. During MV, the jet nebulizer is routinely used to give bronchodilators and other medications (McPeck et al., 2021).

The current study showed that all patients were recruited to pressure control ventilation that assumed to hinder the effective aerosol delivery. This may attribute to changing volumes during inspiration. This result is in line with Patel et al.,
(2013); and Dugernier et al., (2016) who found that the pressure control modes had a lower deposition rate in the ventilator circuit compared to volume control modes. On the other hand, the current result was contradicated with Vecellio et al., (2005) who showed that high pressure volume had no effect on aerosol output.

The current study illustrated that about two thirds of the patients revealed that there is increased value of inspiratory flow and inspiratory bias flow which hinder the distribution of nebulization therapy. These results are in line with Li and Fink (2021) who illustrated that higher inspiratory flow can decrease bronchodilator delivery to the patients. Emeryk et al (2021) approved that there is a significant effect of the inspiratory flow on the amount of aerosol deposition during inhalation therapy.

The calculated duty cycle value in majority of the studied patients was higher than 0.30. This may be attributed to the increasing inspiratory time which gives longer duty cycle. this result is matching with Ari and Fink, (2010) who recommended that the duty cycle equal or higher than 0.30. Berlinski andWillis, (2015), and Ehrmann et al., (2020) demonstrated that higher duty cycle gives higher nebulizer output rate. On the other hand, the current results were contradicted with Vecellio et al., (2005) who stated that there is a negative correlation between duty cycle, and the nebulizer output.

In the current study all the nebulization sessions to all the studied patients were done by using jet nebulizer device. The duration of each nebulization therapy session in more than two thirds of the patients was 6-10 minutes. It is not enough for delivering aerosolized medications. This may be attributed to the device's efficacy that influenced by the ventilator flow which led to incomplete drug delivery. this result is in-line with Liu et al., (2019) who recommended increasing session duration and multiple used doses which is better to compensate the poor delivery from the jet device.

In the current study the jet nebulizer was placed between the airway and the circuit in less than two thirds of the studied patients. The jet nebulizer which is too close for the airway to decrease the drug loss. The results of the current study were in line with Anderson et al., 
(2017); and Peng et al., (2018) who recommended placing the nebulizer device near ventilator, near humidifier inlet or outlet, or placing it before "Y" piece with $30 \mathrm{~cm}$, which increase the nebulizer efficiency.

In the current study the nebulized drug was given without dilution. that makes the drug has no effect. It may be attributed to the fact that the inspired oxygen makes the drug quickly evaporated in the circuit. The result of the current study is contradicted with Saeed, et al.,( 2018) who emphasized that the nebulized drug should be diluted to get effective nebulizer action.

The current study showed that there was a residual volume of the nebulized drug in slightly less than a half of the patients, and the measured residual volume of the nebulized drug in near a quarter of the patients was more than $2.5 \mathrm{ml}$. This may be attributed to over dilution or placing the dose on old dose that may found in the nebulizer.

This result is in line with Yang et al., (2018) who showed that jet nebulizer has a higher residual volume which make it the least efficient device comparable with other nebulization devices.

Regarding the hemodynamic and respiratory status related responses the current study concluded that there was a significant decrease in pulse, mean arterial pressure (MAP), respiratory rate, and improved air entry on both lungs after the nebulization therapy session with 4 hours through the studied days. This indicates that there wasn't any cardiac or respiratory side effects happened from the nebulized drugs. This may be attributed to the fact that the regional effect of the nebulized medications decreased the respiratory effort of the mechanically ventilated patients without side effect on their hemodynamics.

These findings in line with Moustafa et al., (2017); and Singla et al., (2018) who showed that the hemodynamics and respiratory parameters relatively improved shortly after receiving the nebulized drug. On the other hand these results are contradicted with Bodet-Contentin et al., (2019); and Sahitia et al., (2018) who showed that there wasn't no change in the baseline hemodynamics and respiratory parameters after the session.

Regarding the tidal volume and the presence of patient and ventilator desynchrony, there was a significant decrease in the rate of occurrence of patient - ventilator desynchrony and increase in the inspired tidal volume. This result may be attributed to effect of the nebulized drug on decreasing the work of breathing, and the fighting between the patient and ventilator and increasing the tidal volume without any effort from the patients. The results of the current study is in line with Singla et al., (2018) who stated that the drug was effective in decreasing the breathing effort and increasing the respiratory capacity in the studied patients.

Regarding to the nurses' characteristics, the years of experience in ICU in near half of the nurses equal $1-<5$ years. However, none of the studied nurses attended in service education or training about nebulization therapy so almost of the nurses doesn't have any knowledge about the accurate administration procedure. Regarding to total mean score and standard deviation of nebulization therapy steps in the different working shifts, the level of performance was unsatisfactory especially in the night work shift. This may be attributed to lack of the staff experience understaffing and work overload at night shift with minimal resources for caring for the patients especially during administration of performing nebulization therapy.

This results is in line with Zhang et al., (2021);and Zhang et al., (2019) who showed that the level of knowledge of the nurses and their performance were unsatisfactory due to lack of educational programs about the correct administration technique and it must be compensated by frequent educational programs and frequent assessment related to the knowledge and performance level. On the other side the current study was reversed with Ehrmann et al., (2016); and Shakor, (2019) which showed that the practice level was adequate in the comparison with the unsatisfactory level of knowledge. 


\section{Conclusion}

Based upon the findings of the current study, it could be concluded that ventilator parameters should be checked before the nebulization therapy session as slower inspiratory flow, longer duty cycle, and large diameter tracheal tubes gives betters and effective nebulization. The nurses' level of performance during morning and evening shift was satisfactory. There was a significant improvement in hemodynamic status and respiratory parameters after nebulization therapy sessions with 4 hours.

\section{Recommendations}

In line with the findings of the study, the following recommendations are made: Instruct the nurses to assess the ventilator data especially the inspiratory flow and the inspiratory time before the nebulization session., as well as, encouraging nursing staff to turn off the humidifier during the nebulizer.

The preferred position for placing jet nebulizer device is before the ETT and the circuit or 6 inches before the "Y" shape in the inspiratory limb. Provide frequent in-service training programs for the critical care nurses regarding nebulization therapy devices with it is advantages and drawbacks and the correct application on mechanical ventilator and Assess barriers that affect the level of performance related to nebulization therapy at the night shift. 
Table I: Distribution of the patients according to the demographic and health-related data.

\begin{tabular}{|c|c|c|}
\hline Patient data & $\begin{array}{c}\text { No. } \\
(n=60)\end{array}$ & $\%$ \\
\hline \begin{tabular}{|l} 
Demographic data \\
Gender \\
Male \\
Female \\
\end{tabular} & $\begin{array}{l}30 \\
30\end{array}$ & $\begin{array}{l}50.0 \\
50.0\end{array}$ \\
\hline \begin{tabular}{|l} 
Age \\
$18-30$ years \\
$31-40$ years \\
$41-50$ years \\
$51-60$ years
\end{tabular} & $\begin{array}{l}20 \\
10 \\
15 \\
15\end{array}$ & $\begin{array}{l}33.3 \\
16.7 \\
25.0 \\
25.0\end{array}$ \\
\hline \begin{tabular}{|l} 
\#Current Diagnosis \\
Respiratory \\
Cardiovascular \\
Renal \\
Neurological \\
Endocrine \\
\end{tabular} & $\begin{array}{l}60 \\
31 \\
35 \\
22 \\
26\end{array}$ & $\begin{array}{l}100.0 \\
51.7 \\
58.3 \\
36.7 \\
43.3\end{array}$ \\
\hline $\begin{array}{l}\text { Past Medical History } \\
\text { Respiratory } \\
\text { Cardiovascular } \\
\text { Renal } \\
\text { Endocrine }\end{array}$ & $\begin{array}{l}28 \\
30 \\
35 \\
26\end{array}$ & $\begin{array}{l}46.7 \\
50.0 \\
58.3 \\
43.3\end{array}$ \\
\hline $\begin{array}{c}\text { GCS score } \\
3-8 \\
9-11\end{array}$ & $\begin{array}{l}38 \\
22\end{array}$ & $\begin{array}{l}63.3 \\
36.7 \\
\end{array}$ \\
\hline $\begin{array}{l}\text { Length of stay in ICU } \\
1-7 \text { days } \\
8-14 \text { days } \\
15-21 \text { days } \\
22-28 \text { days } \\
>28 \text { days }\end{array}$ & $\begin{array}{c}20 \\
16 \\
5 \\
12 \\
7\end{array}$ & $\begin{array}{c}33.3 \\
26.7 \\
8.3 \\
20.0 \\
11.7\end{array}$ \\
\hline
\end{tabular}

\# Some patients have more than one diagnosis. GCS: Glasgow Coma Scale.

Table II: Distribution of the patients according to ventilator related parameters.

\begin{tabular}{|c|c|c|c|}
\hline \multicolumn{2}{|c|}{ Ventilator parameters } & $\begin{array}{c}\text { No. } \\
(\mathrm{n}=60)\end{array}$ & $\%$ \\
\hline$\underline{\text { Mode of MV }}$ & $\begin{array}{c} \\
\text { BIPAP } \\
\text { PCV } \\
\text { PSV } \\
\text { SIMV + PSV } \\
\text { CPAP + PSV }\end{array}$ & $\begin{array}{c}15 \\
13 \\
5 \\
13 \\
14\end{array}$ & $\begin{array}{c}25.0 \\
21.7 \\
8.3 \\
21.7 \\
23.3\end{array}$ \\
\hline \multicolumn{2}{|c|}{$\begin{array}{c}\text { Inspiratory Flow } \\
\text { <40 L/Min } \\
40 \mathrm{~L} / \mathrm{Min} \\
\text { >40 L/Min }\end{array}$} & $\begin{array}{c}25 \\
5 \\
30\end{array}$ & $\begin{array}{c}41.7 \\
8.3 \\
50.0 \\
\end{array}$ \\
\hline \multicolumn{2}{|c|}{$\begin{array}{l}\text { Bias flow } \\
<2 \mathrm{~L} / \mathrm{Min} \\
\geq 2 \mathrm{~L} / \mathrm{Min} \\
\end{array}$} & $\begin{array}{l}25 \\
35\end{array}$ & $\begin{array}{l}41.7 \\
58.3 \\
\end{array}$ \\
\hline \multicolumn{2}{|c|}{ Duty Cycle } & $\begin{array}{c}5 \\
7 \\
48\end{array}$ & $\begin{array}{l}8.3 \\
11.7 \\
80.0\end{array}$ \\
\hline
\end{tabular}


Table III: Distribution of the patients according to nebulization

\begin{tabular}{|c|c|c|}
\hline Nebulization & $\begin{array}{c}\text { No. } \\
(n=60)\end{array}$ & $\%$ \\
\hline $\begin{array}{l}\text { Type of Aerosol Device Used During the Session } \\
\text { Jet } \\
\text { Ultra sonic } \\
\text { Vibrating mesh } \\
\text { Pressurized metered dose inhalers }\end{array}$ & $\begin{array}{c}60 \\
0 \\
0 \\
0\end{array}$ & $\begin{array}{l}100.0 \\
00.0 \\
00.0 \\
00.0\end{array}$ \\
\hline $\begin{array}{l}\text { Position of The Device in The Circuit } \\
\text { Between the ETT And the Circuit } \\
\text { Inspiratory Limb } 6 \text { Inches From "Y" Shape }\end{array}$ & $\begin{array}{l}36 \\
24\end{array}$ & $\begin{array}{l}60.0 \\
40.0\end{array}$ \\
\hline $\begin{array}{l}\text { Dilution of the nebulized drug } \\
\text { Diluted with } 1 \mathrm{CC} \text { N. S } \\
\text { Not diluted }\end{array}$ & $\begin{array}{l}28 \\
32\end{array}$ & $\begin{array}{l}46.7 \\
53.3\end{array}$ \\
\hline $\begin{array}{l}\text { Fill Volume of the drug in the nebulizer device } \\
2 \mathrm{CC} \\
3 \mathrm{CC}\end{array}$ & $\begin{array}{l}34 \\
26\end{array}$ & $\begin{array}{l}56.7 \\
44.3\end{array}$ \\
\hline $\begin{array}{l}\text { Duration of The Session } \\
5 \text { Min } \\
6-10 \mathrm{Min} \\
11-15 \mathrm{Min}\end{array}$ & $\begin{array}{c}5 \\
43 \\
12\end{array}$ & $\begin{array}{c}8.3 \\
71.7 \\
20.0\end{array}$ \\
\hline $\begin{array}{l}\text { Presence of Residual volume from the Nebulized Drug } \\
\text { Present } \\
\text { Absent }\end{array}$ & $\begin{array}{l}27 \\
33\end{array}$ & $\begin{array}{l}45.0 \\
55.0\end{array}$ \\
\hline $\begin{array}{l}\text { Residual Volume of the Nebulized Drug } \\
0.1-2.5 \mathrm{ml} \\
>2.5 \mathrm{ml}\end{array}$ & $\begin{array}{l}13 \\
14\end{array}$ & $\begin{array}{l}21.7 \\
23.3\end{array}$ \\
\hline
\end{tabular}


Table IV: distribution of the respiratory parameters in patients receiving nebulization therapy

\begin{tabular}{|c|c|c|c|c|c|c|c|c|c|c|c|c|c|c|c|c|c|c|c|c|c|}
\hline \multirow[b]{2}{*}{ Respiratory status } & \multicolumn{6}{|c|}{ 1 $^{\text {st }}$ day } & \multirow[b]{2}{*}{$\begin{array}{l}\text { Test of } \\
\text { sig.(p) }\end{array}$} & \multicolumn{6}{|c|}{$2^{\text {nd }}$ day } & \multirow[b]{2}{*}{$\begin{array}{l}\text { Test of } \\
\text { sig.(p2) }\end{array}$} & \multicolumn{6}{|c|}{$3^{\text {rd }}$ day } & \multirow[b]{2}{*}{$\begin{array}{l}\text { Test of } \\
\text { sig.(p3) }\end{array}$} \\
\hline & \multicolumn{2}{|c|}{$\begin{array}{c}\text { Before } \\
\text { Nebulization }\end{array}$} & \multicolumn{2}{|c|}{$\begin{array}{c}\text { Immediately } \\
\text { after } \\
\text { nebulization }\end{array}$} & \multicolumn{2}{|c|}{$\begin{array}{l}\text { After } 4 \mathrm{hrs} \text {. } \\
\text { from } \\
\text { nebulization }\end{array}$} & & $\begin{array}{r}\text { B } \\
\text { Nebu }\end{array}$ & $\begin{array}{l}\text { ore } \\
\text { zation }\end{array}$ & \multicolumn{2}{|c|}{$\begin{array}{c}\text { Immediately } \\
\text { after } \\
\text { nebulization }\end{array}$} & \multicolumn{2}{|c|}{$\begin{array}{l}\text { After } 4 \text { hrs. } \\
\text { from } \\
\text { nebulization }\end{array}$} & & \multicolumn{2}{|c|}{$\begin{array}{c}\text { Before } \\
\text { Nebulization }\end{array}$} & \multicolumn{2}{|c|}{$\begin{array}{c}\text { Immediately } \\
\text { after } \\
\text { nebulization }\end{array}$} & \multicolumn{2}{|c|}{$\begin{array}{l}\text { After } 4 \text { hrs. } \\
\text { from } \\
\text { nebulization }\end{array}$} & \\
\hline $\begin{array}{l}\text { Respiratory Rate } \\
\text { Mean } \pm \text { SD. }\end{array}$ & \multicolumn{2}{|c|}{$22.98 \pm 4.53$} & \multicolumn{2}{|c|}{$17.72 \pm 1.51$} & \multicolumn{2}{|c|}{$18.17 \pm 2.31$} & $\begin{array}{l}\mathrm{F}=57.11^{*} \\
\left(<0.001^{*}\right)\end{array}$ & \multicolumn{2}{|c|}{$22.10 \pm 4.73$} & \multicolumn{2}{|c|}{$17.47 \pm 1.76$} & \multicolumn{2}{|c|}{$17.57 \pm 1.99$} & $\begin{array}{l}\mathrm{F}=43.80^{*} \\
\left(<0.001^{*}\right)\end{array}$ & \multicolumn{2}{|c|}{$22.25 \pm 4.80$} & \multicolumn{2}{|c|}{$17.48 \pm 1.78$} & \multicolumn{2}{|c|}{$17.67 \pm 2.01$} & $\begin{array}{l}F=45.613^{*} \\
\left(<0.001^{*}\right)\end{array}$ \\
\hline $\begin{array}{l}\text { Air Entry } \\
\text { Right lung }\end{array}$ & No. & $\%$ & No. & $\%$ & No. & $\%$ & \multirow{2}{*}{$\begin{array}{r}\operatorname{Fr}=6.936^{*} \\
\left(0.031^{*}\right)\end{array}$} & No. & $\%$ & No. & $\%$ & No. & $\%$ & \multirow{2}{*}{$\begin{array}{c}\mathrm{Fr}=8.851^{*} \\
\left(0.012^{*}\right)\end{array}$} & No. & $\%$ & No. & $\%$ & No. & $\%$ & \multirow{2}{*}{$\begin{array}{c}\mathrm{Fr}=7.731^{*} \\
\left(0.021^{*}\right)\end{array}$} \\
\hline $\begin{array}{l}\text { Normal } \\
\text { Diminished }\end{array}$ & $\begin{array}{l}18 \\
42\end{array}$ & $\begin{array}{l}30.0 \\
70.0\end{array}$ & $\begin{array}{l}32 \\
28\end{array}$ & $\begin{array}{l}53.3 \\
46.7\end{array}$ & $\begin{array}{l}29 \\
31\end{array}$ & $\begin{array}{l}48.3 \\
51.7\end{array}$ & & $\begin{array}{l}17 \\
43\end{array}$ & $\begin{array}{l}28.3 \\
71.7\end{array}$ & $\begin{array}{l}33 \\
27\end{array}$ & $\begin{array}{l}55.0 \\
45.0\end{array}$ & $\begin{array}{l}29 \\
31\end{array}$ & $\begin{array}{l}48.3 \\
51.7\end{array}$ & & $\begin{array}{l}19 \\
41\end{array}$ & $\begin{array}{l}31.7 \\
68.3\end{array}$ & $\begin{array}{l}35 \\
25\end{array}$ & $\begin{array}{l}58.3 \\
41.7\end{array}$ & $\begin{array}{l}30 \\
30\end{array}$ & $\begin{array}{l}50.0 \\
50.0\end{array}$ & \\
\hline Left lung & No. & $\%$ & No. & $\%$ & No. & $\%$ & \multirow{2}{*}{$\begin{array}{r}\mathrm{Fr}=6.333^{*} \\
\left(0.042^{*}\right)\end{array}$} & No. & $\%$ & No. & $\%$ & No. & $\%$ & \multirow{2}{*}{$\begin{array}{c}\mathrm{Fr}=8.190^{*} \\
\left(0.017^{*}\right)\end{array}$} & No. & $\%$ & No. & $\%$ & No. & $\%$ & \multirow{2}{*}{$\begin{array}{l}\mathrm{Fr}=11.21^{*} \\
\left(0.004^{*}\right)\end{array}$} \\
\hline $\begin{array}{l}\text { Normal } \\
\text { Diminished }\end{array}$ & $\begin{array}{l}23 \\
37\end{array}$ & $\begin{array}{l}38.3 \\
61.7\end{array}$ & $\begin{array}{l}35 \\
25\end{array}$ & $\begin{array}{l}58.3 \\
41.7\end{array}$ & $\begin{array}{l}34 \\
26\end{array}$ & $\begin{array}{l}56.7 \\
34.3\end{array}$ & & $\begin{array}{l}25 \\
35\end{array}$ & $\begin{array}{l}41.7 \\
58.3\end{array}$ & $\begin{array}{l}39 \\
21\end{array}$ & $\begin{array}{l}65.0 \\
35.0\end{array}$ & $\begin{array}{l}37 \\
23\end{array}$ & $\begin{array}{l}61.7 \\
38.3\end{array}$ & & $\begin{array}{l}22 \\
38\end{array}$ & $\begin{array}{l}36.7 \\
63.3\end{array}$ & $\begin{array}{l}38 \\
22\end{array}$ & $\begin{array}{l}63.3 \\
36.7\end{array}$ & $\begin{array}{l}37 \\
23\end{array}$ & $\begin{array}{l}61.7 \\
38.3\end{array}$ & \\
\hline $\begin{array}{l}\text { VT } \\
\text { Mean } \pm \text { SD. }\end{array}$ & \multicolumn{2}{|c|}{$543.1 \pm 86.37$} & \multicolumn{2}{|c|}{$696.8 \pm 125$} & \multicolumn{2}{|c|}{$590.0 \pm 58.7$} & $\begin{array}{l}\mathrm{F}=40.18^{*} \\
\left(<0.001^{*}\right)\end{array}$ & 543. & $=91.0$ & $683 \pm$ & 10.2 & 602 & \pm 72 & $\begin{array}{l}\mathrm{F}=39.78^{*} \\
\left(<0.001^{*}\right)\end{array}$ & 554. & $=91.2$ & 690. & \pm 137 & 581. & +74.9 & $\begin{array}{l}\mathrm{F}=31.557^{*} \\
\left(<0.001^{*}\right)\end{array}$ \\
\hline $\begin{array}{l}\text { Patient -ventilator } \\
\text { synchronization }\end{array}$ & No. & $\%$ & No. & $\%$ & No. & $\%$ & $\mathrm{Fr}=50.24^{*}$ & No. & $\%$ & No. & $\%$ & No. & $\%$ & $\mathrm{Fr}=48.27^{*}$ & No. & $\%$ & No. & $\%$ & No. & $\%$ & $\mathrm{Fr}=58.80^{*}$ \\
\hline $\begin{array}{l}\text { No } \\
\text { Yes }\end{array}$ & $\begin{array}{l}35 \\
25\end{array}$ & $\begin{array}{l}58.3 \\
41.7\end{array}$ & $\begin{array}{l}22 \\
38\end{array}$ & $\begin{array}{l}36.7 \\
63.3\end{array}$ & $\begin{array}{c}2 \\
58\end{array}$ & $\begin{array}{c}3.3 \\
96.7\end{array}$ & $\left(<0.001^{*}\right)$ & $\begin{array}{l}32 \\
28\end{array}$ & $\begin{array}{l}53.3 \\
46.7\end{array}$ & $\begin{array}{l}24 \\
36\end{array}$ & $\begin{array}{l}40.9 \\
60.0\end{array}$ & $\begin{array}{c}2 \\
58\end{array}$ & $\begin{array}{c}3.3 \\
96.7\end{array}$ & $\left(<0.001^{*}\right)$ & $\begin{array}{l}38 \\
22\end{array}$ & $\begin{array}{l}63.3 \\
36.7\end{array}$ & $\begin{array}{l}31 \\
39\end{array}$ & $\begin{array}{l}51.7 \\
48.3\end{array}$ & $\begin{array}{c}3 \\
57\end{array}$ & $\begin{array}{c}5.0 \\
95.0\end{array}$ & $\left(<0.001^{*}\right)$ \\
\hline
\end{tabular}

F: F test (ANOVA) with repeated measures

$\mathrm{p}_{1}$ : $\mathrm{p}$ value for comparing between the studied periods in $1^{\text {st }}$ day

$\mathrm{p}_{3}$ : $\mathrm{p}$ value for comparing between the studied periods in $3^{\text {rd }}$ day
Fr: Friedman test

$\mathrm{p}_{2}$ : $\mathrm{p}$ value for comparing between the studied periods in $2^{\text {nd }}$ day

*: Statistically significant at $\mathrm{p} \leq 0.05$ 
Table V: Distribution of the critical care nurses according to their characteristics

\begin{tabular}{|c|c|c|}
\hline Nurses' characteristics & $\begin{array}{c}\text { No. } \\
(n=60)\end{array}$ & $\%$ \\
\hline $\begin{array}{l}\text { Age }(\text { years }) \\
\quad<25 \\
\quad 25-35\end{array}$ & $\begin{array}{l}39 \\
21\end{array}$ & $\begin{array}{l}65.0 \\
35.0\end{array}$ \\
\hline $\begin{array}{l}\text { Gender } \\
\text { Male } \\
\text { Female }\end{array}$ & $\begin{array}{l}31 \\
29\end{array}$ & $\begin{array}{l}51.7 \\
48.3 \\
\end{array}$ \\
\hline $\begin{array}{l}\text { Level of education } \\
\text { Baccalaureate } \\
\text { Technical } \\
\text { Diploma }\end{array}$ & $\begin{array}{l}34 \\
14 \\
12\end{array}$ & $\begin{array}{l}56.7 \\
23.3 \\
20.0\end{array}$ \\
\hline $\begin{array}{l}\text { Years of Experience in Intensive care unit } \\
\quad<1 \mathrm{YR} \\
1<5 \mathrm{YR} \\
5<10 \mathrm{YR}\end{array}$ & $\begin{array}{l}20 \\
28 \\
12\end{array}$ & $\begin{array}{l}33.3 \\
46.7 \\
20.0\end{array}$ \\
\hline $\begin{array}{l}\text { Attendance of In-Service Education Regarding Nebulization Therapy } \\
\text { yes } \\
\text { No }\end{array}$ & $\begin{array}{c}0 \\
60\end{array}$ & $\begin{array}{c}00.0 \\
100.0\end{array}$ \\
\hline
\end{tabular}

Table VI: Comparison between the critical care nurses' level of performance of nebulization therapy during different working shifts.

\begin{tabular}{|c|c|c|c|c|c|c|c|c|}
\hline \multirow[t]{2}{*}{ Nebulization therapy performance } & \multicolumn{2}{|c|}{ Morning shift } & \multicolumn{2}{|c|}{ Evening shift } & \multicolumn{2}{|c|}{ Night shift } & \multicolumn{2}{|c|}{ Significance } \\
\hline & No. & $\%$ & No. & $\%$ & No. & $\%$ & Fr & $\mathbf{p}$ \\
\hline \multicolumn{9}{|l|}{ Total score } \\
\hline$<75 \%$ Unsatisfactory & 50 & 83.3 & 56 & 93.3 & 58 & 96.7 & $10.400^{*}$ & $0.006^{*}$ \\
\hline$\geq 75 \%$ Satisfactory & 10 & 16.7 & 4 & 6.7 & 2 & 3.3 & & \\
\hline Mean \pm SD. Total score & \multicolumn{2}{|c|}{$60.23 \pm 19.73$} & \multicolumn{2}{|c|}{$55.53 \pm 13.05$} & \multicolumn{2}{|c|}{$53.82 \pm 10.45$} & \multirow{2}{*}{$5.424^{*}$} & \multirow{2}{*}{$0.006^{*}$} \\
\hline Mean \pm SD. $\%$ Score & \multicolumn{2}{|c|}{$49.90 \pm 16.14$} & \multicolumn{2}{|c|}{$45.99 \pm 10.56$} & \multicolumn{2}{|c|}{$44.63 \pm 8.45$} & & \\
\hline
\end{tabular}

Fr: Friedman test $\quad$ F: F test (ANOVA) with repeated measures

$\mathrm{p}$ : $\mathrm{p}$ value for comparing between the studied shifts $\quad *$ : Statistically significant at $\mathrm{p} \leq 0.05$ 


\section{References}

- Aithal, S., S. V., J., andS., N. (2017). Knowledge and attitude of nursing staff towards nebulization therapy in a tertiary care hospital. International Journal of Research in Medical Sciences, $\quad 5(9), \quad 3976$. https://doi.org/10.18203/23206012.ijrms20173965

- Anderson, A. C., Dubosky, M. N., Fiorino, K. A., Quintana, V., Kaplan, C. A., andVine, D. L. (2017). The effect of nebulizer position on aerosolized epoprostenol delivery in an adult lung model. Respiratory Care, 62(11), 13871395.

https://doi.org/10.4187/respcare.05344

- Ari, A., andFink, J. B. (2010). Factors affecting bronchodilator delivery in mechanically ventilated adults. Nursing in CriticalCare,15(4),192-203. https://doi.org/10.1111/j.14785153.2010.00395.X

- Poornowrooz Ball, L., Sutherasan, Y., Caratto, V., Sanguineti, E., Marsili, M., Raimondo, P., Ferretti, M., Kacmarek, R. M., andPelosi, P. (2016). Effects of nebulizer position, gas flow, and CPAP on aerosol bronchodilator delivery: An in vitro study. Respiratory Care, 61(3), 263-268. https://doi.org/10.4187/respcare.04275

- Berlinski, A., andRandy Willis, J. (2013). Albuterol delivery by 4 different nebulizers placed in 4 different positions in a pediatric ventilator in vitro model. Respiratory Care, 58(7),1124-1133. https://doi.org/10.4187/respcare.02074.

- Bodet-Contentin, L., Guillon, A., Boulain, T., Frat, J. P., Garot, D., Le Pennec, D., Vecellio, L., Ehrmann, S., Giraudeau, B., Tavernier, E., andDequin, P. F. (2019). Salbutamol Nebulization During Noninvasive Ventilation in Exacerbated Chronic Obstructive Pulmonary Disease Patients: A Randomized Controlled Trial. Journal of Aerosol Medicine and Pulmonary Drug Delivery, 32(3), 149155. https://doi.org/10.1089/jamp.2018.1484.

- Dhanani, J. A., Tang, P., Wallis, S. C., Parker, S. L., Pandey, P., Fraser, J. F., Cohen, J., Barnett, A., Roberts, J. R., andChan, H. K. (2018). Characterisation of $40 \mathrm{mg} / \mathrm{ml}$ and $100 \mathrm{mg} / \mathrm{ml}$ tobramycin formulations for aerosol therapy with adult MV. Pulmonary Pharmacology and Therapeutics, 50(February), 93-99. https://doi.org/10.1016/j.pupt.2018.04.0 06

- Dhand, R. (2003). Maximizing aerosol delivery during MV: Go with the flow and go slow. Intensive Care Medicine, 29(7),1041-1042.

https://doi.org/10.1007/s00134-0031791-2

- Dhand, R. (2013). BRONCHODILATOR THERAPY. In M. J. Tobin (Ed.), Principles and Practice of $M V$ (3rd ed., pp. 14161446). McGraw-Hill Companies.

- Dugernier, J., Reychler, G., Wittebole, X., Roeseler, J., Depoortere, V., Sottiaux, T., Michotte, J. B., Vanbever, R., Dugernier, T., Goffette, P., Docquier, M. A., Raftopoulos, C., Hantson, P., Jamar, F., andLaterre, P. F. (2016). Aerosol delivery with two ventilation modes during MV: a randomized study. Annals of Intensive Care, 6(1). https://doi.org/10.1186/s13613016-0169-x

- Dugernier, J., Wittebole, X., Roeseler, J., Michotte, J. B., Sottiaux, T., Dugernier, T., Laterre, P. F., andReychler, G. (2015). Influence of inspiratory flow pattern and nebulizer position on aerosol delivery with a vibrating-mesh nebulizer during invasive MV: An in vitro analysis. Journal of Aerosol Medicine and Pulmonary Drug Delivery,28(3),229236.

https://doi.org/10.1089/jamp.2014.1131.

- Ehrmann, S., andLuyt, C. E. (2020). Optimizing aerosol delivery of antibiotics in ventilated patients. In Current opinion in infectious diseases (Vol. 33, Issue 2). https://doi.org/10.1097/QCO.000000000 0000633

- Ehrmann, S., Roche-Campo, F., BodetContentin, L., Razazi, K., Dugernier, J., Trenado-Alvarez, J., Donzeau, A., Vermeulen, F., Thévoz, D., Papanikolaou, M., Edelson, A., León Yoshido, H., Piquilloud, L., Lakhal, K., Lopes, C., Vicent, C., Desachy, A., Apiou-Sbirlea, G., Isabey, D., andBrochard, L. (2016). Aerosol therapy in intensive and intermediate care units: prospective observation of 2808 
critically ill patients. Intensive Care Medicine, 42(2), 192-201. https://doi.org/10.1007/s00134-0154114-5

- El-khatib, M. F. (2016). humidity and aerosol therapy. In T. A. Volsko andM. F. El-khatib (Eds.), equipment for respiratory care (pp. 75-95). Jones andBartlett Learning.

- Ellis, A., Van Aswegen, H., Ross, R., andBecker, P. (2013). Contamination and current practice in decontamination pof nebulisers in ventilated patients. South African Journal of Physiotherapy, 69(4).

https://doi.org/10.4102/sajp.v69i4.373

- Emeryk, A., Emeryk-Maksymiuk, J., andJaneczek, K. (2021). Inspiratory flows and the aerosol cloud from dry powder inhalers. Alergoprofil,17(2). https://doi.org/10.24292/01.ap.17231052 1

- FINK, J. B., andARI, A. (2017). Aerosol Drug Therapy. In R. M. Kacmarek, J. K. Stoller, A. J. Heuer, R. L. Chatburn, andR. H. Kallet. (Eds.), Egan's fundamentals of respiratory care (11th ed., pp. 834-883). ELSEVIER.

- J.M.Cairo. (2016). Initial Patient Assessment. In J. M. Cairo (Ed.), Pilbeam's MV: physiological and clinical applications (6th ed., pp. 118141). ELSEVIER.

- Li, J., andFink, J. B. (2021). Narrative review of practical aspects of aerosol delivery via high-flow nasal cannula. Annals of Translational Medicine, 9(7). https://doi.org/10.21037/atm-20-7383

- Liu, C. Y., Ko, H. K., Fink, J. B., Wan, G. H., Huang, C. C., Chen, Y. C., andLin, H. L. (2019). Size distribution of colistin delivery by different type nebulizers and concentrations during MV. Pharmaceutics, 11(9),1-11. https://doi.org/10.3390/pharmaceutics11 090459

- Maccari, J. G., Teixeira, C., Gazzana, M. B., Savi, A., Dexheimer-Neto, F. L., andKnorst, M. M. (2015). Inhalation therapy in MV. Jornal Brasileiro de Pneumologia, 41(5), 467-472. https://doi.org/10.1590/S1806$\underline{37132015000000035}$

- McPeck, M., Ashraf, S., Cuccia, A. D., andSmaldone, G. C. (2021). Factors determining continuous infusion aerosol delivery during MV. Respiratory Care, 66(4),573-581.

https://doi.org/10.4187/respcare.0771 $\underline{5}$

- Mohamed, H. S., andMeguid, M. M. A. (2017). Effect of nebulized budesonide on respiratory mechanics and oxygenation in acute lung injury/acute respiratory distress syndrome: Randomized controlled study. Saudi Journal of Anaesthesia, 11(1), 9-14. https://doi.org/10.4103/1658354X.197369

- Moustafa, I. O. F., ElHansy, M. H. E., Al Hallag, M., Fink, J. B., Dailey, P., Rabea, H., andAbdelrahim, M. E. A. (2017). Clinical outcome associated with the use of different inhalation method with and without humidification in asthmatic mechanically ventilated patients. Pulmonary Pharmacology and Therapeutics, 45, 40-46. https://doi.org/10.1016/j.pupt.2017.0 4.007

- Patel, R. B., Smaldone, G. C., Cuccia, A. D., andStrachan, P. (2013). In vitro delivery of aerosolized treprostinil via modern MV. Journal of Aerosol Medicine and Pulmonary Drug Delivery, 26(4), 200-207. https://doi.org/10.1089/jamp.2012.10 $\underline{13}$

- Peng, Y., Dai, B., Hu, C. X., Su, J., Tan, W., Zhao, H. W., andKang, J. (2018). Which Nebulizer Position Should Be Avoided? An Extended Study of Aerosol Delivery and Ventilator Performance during Noninvasive Positive Pressure Ventilation. Respiration, 95(3), 145-153. https://doi.org/10.1159/000481868

- Piraino, T. (2017). monitoring the patient in the intensive care unit. In R. M. kacmarek, J. K. stoller, andA. J. heuer (Eds.), EGAN'S FUNDAMENTALS OF RESPIRATORY CARE (11th ed., pp. 1154-1189). ELSEVIER.

- Saeed, H., Abdelrahim, M., andFink, J. (2018). Stability of commonly nebulized drugs in heated and humid condition. Medicine Science | International Medical Journal, $\quad 7(2), 1$. 
https://doi.org/10.5455/medscience. 2 $\underline{017.06 .8737}$

- Saeed, H., Mohsen, M., Eldin, A. S., Elberry, A. A., Hussein, R. R. S., Rabea, H., andAbdelrahim, M. E. A. (2018). Effects of fill volume and humidification on aerosol delivery during single-limb noninvasive ventilation. Respiratory Care, 63(11), 1370-1378. https://doi.org/10.4187/respcare.0602 $\underline{2}$

- Sahitia, S., Imtiaz, S., Jafry, A., Muhammad, S., Hyder, Z., Anjum, N., andAnwar, A. (2018). Assessment of Pressurised Metered Dose Inhaler Technique of Nursing Staff in Different Government Hospitals of Karachi. 23(23), 23-28.

- Shakor, S. Q. (2019). KUFA JOURNAL FOR NURSING SCIENCES . VOL . 9 No . 2 / 2019 Knowledge and practices of nurses regarding nebulization therapy in Kirkuk city hospitals ,Kufa Journal for Nursing Sciences, 9(2), 1-9.

- Singla, J., Chopra, S., Sudan, D., Sharma, S., Kumar, N., andKapoor, V. (2018). Comparison of FormoterolBudesonide Formulation Nebulized Alone and in Combination With Ipratropium Bromide Formulation in Patients With Chronic Obstructive Pulmonary Disease. International Journal of Advanced Research, 6(3), 131-136. https://doi.org/10.21474/ijar01/6658

- Sutherasan, Y., Ball, L., Raimondo, P., Caratto, V., Sanguineti, E., Costantino, F., Ferretti, M., Kacmarek, R. M., andPelosi, P. (2017). Effects of ventilator settings, nebulizer and exhalation port position on albuterol delivery during non-invasive ventilation: An in-vitro study. BMC Pulmonary Medicine, $17(1)$. https://doi.org/10.1186/s12890-016$\underline{0347-5}$

- Vecellio, L., Guérin, C., Grimbert, D., De Monte, M., andDiot, P. (2005). In vitro study and semiempirical model for aerosol delivery control during MV. Intensive Care Medicine, 31(6), 871876. https://doi.org/10.1007/s00134005-2594-4
- Yang, S. H., Yang, T. M., Lin, H. L., Tsai, Y. H., Fang, T. P., andWan, G. H. (2018). Size distribution of salbutamol/ipratropium aerosols produced by different nebulizers in the absence and presence of heat and humidification. Pulmonary Pharmacology and Therapeutics, 48, 22-27. https://doi.org/10.1016/j.pupt.2017.1 $\underline{0.009}$

- Zhang, C., Mi, J., Wang, X., Lv, S., Zhang, Z., Nie, Z., Luo, X., Gan, R., Zou, Y., Chen, X., Fan, L., Chen, Y., Zhao, H., andLiao, G. (2021). Knowledge and current practices of ICU nurses regarding aerosol therapy for patients treated with invasive MV: a nationwide cross-sectional study. Journal of Clinical Nursing. https://doi.org/10.1111/jocn.1563

- Zhang, Z., Xu, P., Fang, Q., Ma, P., Lin, H., Fink, J. B., Liang, Z., Chen, R., andGe, H. (2019). Practice pattern of aerosol therapy among patients undergoing MV in mainland China: A web-based survey involving 447 hospitals. PLoS ONE, 14(8), 1-12. https://doi.org/10.1371/journal.pone.02 $\underline{21577}$ 